\title{
ASSESSMENT OF THE DEVELOPMENT OF A BORDER AREA USING POLAND'S EASTERN BORDERLAND AS AN EXAMPLE
}

Agnieszka Malkowska ${ }^{1}$, Ph.D.; Arkadiusz Malkowski ${ }^{2}$, Ph.D.

${ }^{1}$ University of Szczecin, Faculty of Management and Economics of Services; ${ }^{2}$ West Pomeranian University of Technology in Szczecin, Faculty of Economics

Abstract. Socioeconomic development is one of the major research topics undertaken in economic sciences. It is a multidimensional and wide concept. The problems discussed in this paper are extremely essential not only from the point of view of countries, but also their regions and smaller territorial units. The development of border areas as one aspect of the aforementioned phenomenon is an important and interesting matter to look at. Such areas are universally regarded as peripheral and less-developed. Peripherality is a complex notion, although it is accepted that geographic accessibility is not the only or prevailing determinant of the development of lands situated along state borders. The purpose of this paper is to assess the socioeconomic development of Poland's eastern borderland. The borderland encompasses three regions, or voivodeships: Podlaskie, Lubelskie and Podkarpackie. Perkal's Index was used to assess the level of their socioeconomic development. The data to build the model on was derived from the Central Statistical Office. The analysis was carried out for 2004 and 2016 for all the 16 voivodeships of Poland, which allowed for comparisons to be made between them. The research showed that the level of socioeconomic development differed between the regions. In 2004, the three eastern borderland voivodeships scored the lowest in terms of the development indices when compared to the rest of the country. By 2016, the situation of the regions concerned had slightly improved. Among them, Podkarpackie Voivodeship had developed the most.

Key words: socioeconomic development, border area, Poland's eastern borderland, Perkal's synthetic index. JEL code: 012

\section{Introduction}

The issues of socioeconomic development are of utter significance, and are thus explored within many academic disciplines. The approach to socioeconomic development and to the factors that determine it has evolved in time. The economic literature sources concerned with this subjectmatter focus on, inter alia, identifying the main factors of development and determining and analysing the so-called growth and stagnation areas. While socioeconomic development research can be conducted on many planes, one of the most essential and interesting of them is that of the development of border regions, which are popularly believed to be peripheral. The purpose of this paper is to assess the socioeconomic development of Poland's eastern borderland. The area encompasses three voivodeships (Podlaskie, Lubelskie and Podkarpackie), directly borders Lithuania, Belarus and Ukraine, accounts for $20.2 \%$ of Poland's area, and has a population of over 5.4 million.

As the research material, Polish and foreign literature concerned with the subject-matter, strategic documents, and statistical data from the Central Statistical Office's Regional Data Bank were used. Perkal's Index (Polish acronym WP), one of the available multidimensional comparative analysis methods, was used as the tool for assessing the socioeconomic development. It was calculated for 2004 and 2016 for all the 16 regions of Poland. This allowed for comparisons to be made across time and against the background of the remaining regions of the country. The period of study was selected so that it could offer uniform statistical data.

\section{Research results and discussion \\ 1. Research method}

Numerous measures are used in studies of the development of territorial units (Strahl D., 2006), but there is not a perfect one there that would, on its own, allow us to evaluate 
the level of development and indicate whether the given region is better developed than others (Slaby T., 2004). For measuring the socioeconomic development of regions, both synthetic indices that cover the whole economy, and fragmentary ones that only show sections of it, are used. The synthetic indices are a function aggregating fragmentary information contained within particular assessment indices and allow for a general assessment of the development to be made (Kucinski K., 2009). The paper was developed using the multidimensional comparative analysis method, and more specifically - Perkal's synthetic index (WP) (Szymla Z., 2005).

The index building procedure entailed constructing a synthetic index that is a sum of standardized fragmentary indices, and followed these stages: 1. Selecting variables, 2. Standardization, 3. Changing destimulants into stimulants, 4. Determining the synthetic index. The observation matrix was created by describing each of the voivodeships with 11 indices.

The variable selection criteria cannot be of a universal nature (Heffner K., Gibas P. , 2007). Such variables were selected that are essential from the point of view of the socioeconomic development of border areas, and take into account their potential for development, the inhabitants' entrepreneurial tendencies and their problems, and relationships with the abroad. At the same time, the data for the years 2004 and 2016 was available in an identical form, which allowed for comparisons to be made across time, and for any changes to be observed.

The following were qualified as diagnostic variables:

x1 - registered unemployment rate (NTS-4, data for the years 2004 and 2016),

x2 - demographic dependency ratio - non-working age population per 100 working-age people,

x3 - gross domestic product per capita,

x4 - persons employed in the R\&D sector - per 1000 professionally active people,

$x 5$ - expenditure on innovative activity in industrial enterprises,

$x 6$ - entities newly-registered in the REGON registry per 1000 inhabitants,

$x 7$ - entities registered in the REGON registry per 10 thousand inhabitants,

$x 8$ - entities with foreign capital per 10 thousand inhabitants,

x9 - municipal expenditure per inhabitant in PLN,

x10 - municipalities' own income per inhabitant,

x11 - R\&D expenditure per capita.

According to the model's assumptions, the variables were standardized because they possessed different weights, which would have otherwise prevented them from being used for direct comparisons. In the next stage, Perkal's synthetic index was constructed as a sum of standardized fragmentary values:

$$
W P=\frac{1}{n} \sum_{j=1}^{n} y_{i j}^{\prime}
$$

where:

WP - stands for Perkal's index

$y^{\prime} i j$ - stands for standardized value of the jth property in the ith object, after destimulants were changed to stimulants

$\mathrm{n}$ - stands for the number of objects

Unit classification was performed on the basis of the Perkal's index (WP) values obtained. The classes were determined on the basis of the arithmetic mean and standard deviation (Tab. 1.). 


\section{Object classification using the mean value and standard deviation}

Source: author's own work

\begin{tabular}{|l|l|l|}
\hline Class & \multicolumn{1}{|c|}{ Range } & Level of development \\
\hline 1. & $W P>\bar{x}+s$ & very good \\
\hline 2. & $\bar{x}<W P<\bar{x}+s$ & Good \\
\hline 3. & $\bar{x}-s<W P<\bar{x}$ & Average \\
\hline 4. & $W P<\bar{x}-s$ & Poor \\
\hline
\end{tabular}

The research procedure allowed for the construction of a synthetic measure of socioeconomic development for all the voivodeships, and for an assessment of the regions of Poland's eastern borderland in terms of the aspect concerned.

\section{The concept and essence of socioeconomic development}

The concept of "development" is a multi-level one, with no universal and generally accepted definition offered to date. There is actually a consensus that the concept is an ambiguous one (Domamski B., 2004). Therefore, in order to ensure a thorough research process and a deeper analysis of the issues related to development, further clarification of this category is required (for instance, by narrowing it down to its local, regional or socioeconomic dimensions). By this, we can avoid the difficulties related to defining it both as it comes to its substantive content and the method for measuring the level of development (Szewczuk A., 2011).

In Poland, regional development is analysed on the voivodeship level. B. Berry, E. Conkling and D.M. Ray (1976) claim that development is a special type of change which takes the form of the restructuring of certain elements of the economic system. These changes take the form of constantly replacing the current state of affairs with its better equivalent, i.e. one that is assessed positively using the assumed criteria (Gluszczuk D., 2011). Obviously, this not only regards the economic and social planes, but also the technical, technological and ecological ones. Social development is a condition precedent for economic development, and vice versa. One cannot exist without the other, whereas both of these elements make up a mechanism driving the 'virtuous circle'. The fact that both these basic components of development are prerequisites for each other turns out to be of significance in the long run (Gorniak J., Mazur S., 2012).

The development of border areas is determined by many factors (Greta M., 2013). In this case, however, a note also needs to be made of the processes and events occurring on the other side of the border, as well as the fact that the areas concerned are in a sense peripheral (Malkowski A., 2015) - or located far from the centre - regions (Idczak P. , 2013). One classic characteristic of peripheral areas is their substantial distance from the main agglomerations and chief economic activity centres, which generates higher costs of transport and travel (Copus A.K., 2001). Nevertheless, in the time of globalization, with considerably reduced costs of transport and travel, this characteristic is insufficient to render their sound description. Other factors (of the so-called non-spatial peripherality) defining peripheral regions include, inter alia: poorly developed information infrastructure, poorly qualified human capital, fragmentary local business networks, weak civil society, institutional ineffectiveness, and undeveloped global connections (Copus A. K.,2001). Thus, the development of border areas is affected by a larger number of stimuli, which makes this process more complex than in other parts of the country (Malkowska A., Malkowski A., 2013). 


\section{Assessment of the socioeconomic development of Poland's eastern borderland}

The results of our research suggest that the level of development of particular regions in Poland is diverse (Tab. 2.). Among of the four classes named, the eastern borderland voivodeships demonstrated the lowest development indices in 2004. Podkarpackie Voivodeship was the weakest of them (WP $=-0.92$ ), with the subsequent positions occupied by Swietokrzyskie (WP $=-0.85$ ) and Lubelskie (W $\mathrm{P}=-0.84$ ). Only Podlaskie was qualified among satisfactorily developed voivodeships in 2004. It must be noted, however, that Podlaskie scored the lowest in this group (WP $=-0.71$ ).

Classification of the level of socioeconomic development of voivodeships in 2004 and 2016 taking into account Perkal's synthetic index

\begin{tabular}{|c|c|c|c|c|c|}
\hline $\begin{array}{l}\text { VOIVODESHIP } \\
\text { (REGION) }\end{array}$ & WP 2004 & ASSESSMENT & VOIVODESHIP (REGION) & WP 2016 & ASSESSMENT \\
\hline MAZOWIECKIE & 2.19 & very good & MAZOWIECKIE & 2.09 & very good \\
\hline DOLNOSLASKIE & 0.66 & \multirow{7}{*}{ good } & DOLNOSLASKIE & 0.64 & \multirow{6}{*}{ good } \\
\hline POMORSKIE & 0.45 & & POMORSKIE & 0.58 & \\
\hline WIELKOPOLSKIE & 0.42 & & MALOPOLSKIE & 0.47 & \\
\hline SLASKIE & 0.40 & & WIELKOPOLSKIE & 0.40 & \\
\hline ZACHODNIOPOMORSKIE & 0.34 & & ZACHODNIOPOMORSKIE & 0.13 & \\
\hline MALOPOLSKIE & 0.15 & & SLASKIE & 0.12 & \\
\hline LUBUSKIE & 0.05 & & LUBUSKIE & -0.13 & \multirow{7}{*}{ satisfactory } \\
\hline LODZKIE & -0.03 & \multirow{5}{*}{ satisfactory } & LODZKIE & -0.19 & \\
\hline KUJAWSKO-POMORSKIE & -0.32 & & OPOLSKIE & -0.22 & \\
\hline OPOLSKIE & -0.37 & & KUJAWSKO-POMORSKIE & -0.47 & \\
\hline WARMINSKO-MAZURSKIE & -0.63 & & PODLASKIE & -0.56 & \\
\hline PODLASKIE & -0.71 & & PODKARPACKIE & -0.57 & \\
\hline LUBELSKIE & -0.84 & \multirow{3}{*}{ insufficient } & WARMINSKO-MAZURSKIE & -0.64 & \\
\hline SWIETOKRZYSKIE & -0.85 & & LUBELSKIE & -0.78 & \multirow{2}{*}{ insufficient } \\
\hline PODKARPACKIE & -0.92 & & SWIETOKRZYSKIE & -0.87 & \\
\hline
\end{tabular}

Source: author's own work.

Both the decade of economic transformation in Poland and a strategic treatment of Poland's eastern borderland voivodeships have brought the expected changes in the level of these regions' development. All the subsequent programs under which additional financial support (including from the EU) was assigned to development projects in the so-called Eastern Poland have inspired clear economic recovery in those areas. This particularly applies to Podkarpackie Voivodeship, which in 2016 achieved distinctly better Perkal's Index results than in 2004. From the position of Poland's weakest region, it moved up to the $13^{\text {th }}$ place. In 2016, it joined the group of voivodeships enjoying a satisfactory level of socioeconomic development. This should be regarded as a visible proof of the effectiveness of the pro-growth actions undertaken in this region. The region's production potential is concentrated within the means of transport and aviation domains. The research showed that in 20016 Podlaskie Voivodeship reached the highest WP (WP =-0.56) score among all eastern borderland voivodeships. In the same year, Lubelskie Voivodeship took the last place among them. What is characteristic here is that when compared to 2004, this region dropped from the $14^{\text {th }}$ place to the $15^{\text {th }}$ and continued to be classified among the lowest development index regions. 
One of the indices used for the purposes of assessing a region's economic situation is gross domestic product per capita, an all-purpose and universally accepted measure. Its analysis showed that the borderland concerned was still characterized by regional inequalities, both with regard to its position within the external system (i.e. the Polish border area on the one hand and the neighbouring and clearly poorer regions of Ukraine and Belarus on the other), but also the internal system (the centre - peripheries relationship). In this context, Mazowieckie Voivodeship, which is Poland's strongest region and, at the same time, the direct support base for the eastern borderland voivodeships, is worth taking note of. Unfortunately, this area delivers a clear picture of developmental polarization to the benefit of the centre at the expense of the borderland.

Among the factors determining a region's development, investments are one of the major ones. A region's borderland and transit-area nature indicates it should be also attractive to potential investors. This particularly applies to export activity aiming at the eastern markets. Research showed a slight increase in foreign investor interest in Poland's eastern borderland (Malkowski A., Malkowska A., 2017). The number of registered enterprises with foreign capital increased markedly. This, however, does not change the fact that this area is characterized by the lowest number of enterprises with foreign capital per capita among all of the country's regions (Fig. 1.).

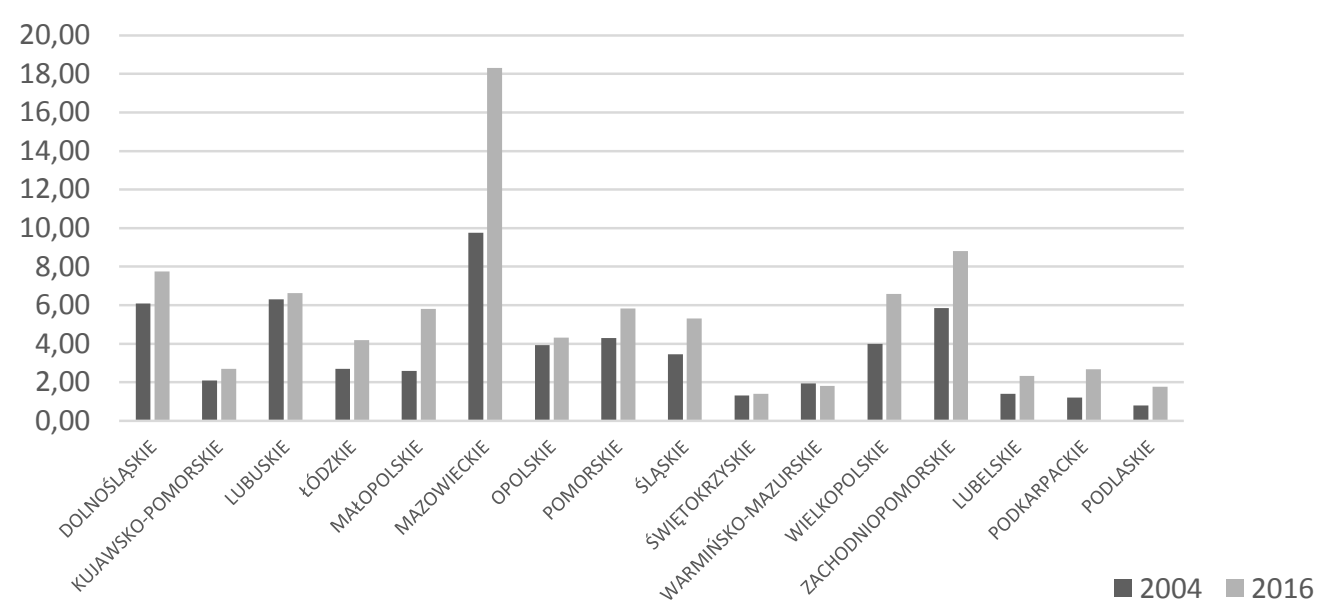

Source: Central Statistical Office

Fig. 1. Enterprises with foreign capital per 10 thousand inhabitants of Polish voivodeships

The data used in this model show that R\&D expenditure increased considerably in Poland's eastern borderland voivodeships. In the case of Podkarpackie Voivodeship, such expenditure grew by a factor of six. In this voivodeship, PLN 50 was spent per capita in 2004, and PLN 358 already in 2006. Lubelskie and Podkarpackie voivodeships saw increased R\&D expenditure, as well. It is worth adding that the highest values of innovation potential development in Poland between 2010 and 2015 were demonstrated by two regions of the country's eastern borderland: Lubelskie and Podkarpackie Voivodeships (Indeks Millenium, 2017).

The eastern borderland voivodeships are characterized by Poland's lowest entrepreneurial activity rates. The number of enterprises registered with the REGON system per capita places these voivodeships in the last three positions in the country. Both in 2004 and 2016, the lowest numbers of enterprises per capita were registered in Podkarpackie voivodeship. There were 665 per 10 thousand inhabitants in 2004, and 788 in 2016, respectively. In the case of Lubelskie Voivodeship, this number amounted to 684 (2004) and 816 (2016), and in Podlaskie Voivodeship 
to 758 (2004) and $842(2016)$. Such a low number of enterprises per 10 thousand inhabitants is also indicative of the amount of unused potential still lying dormant in the eastern borderland.

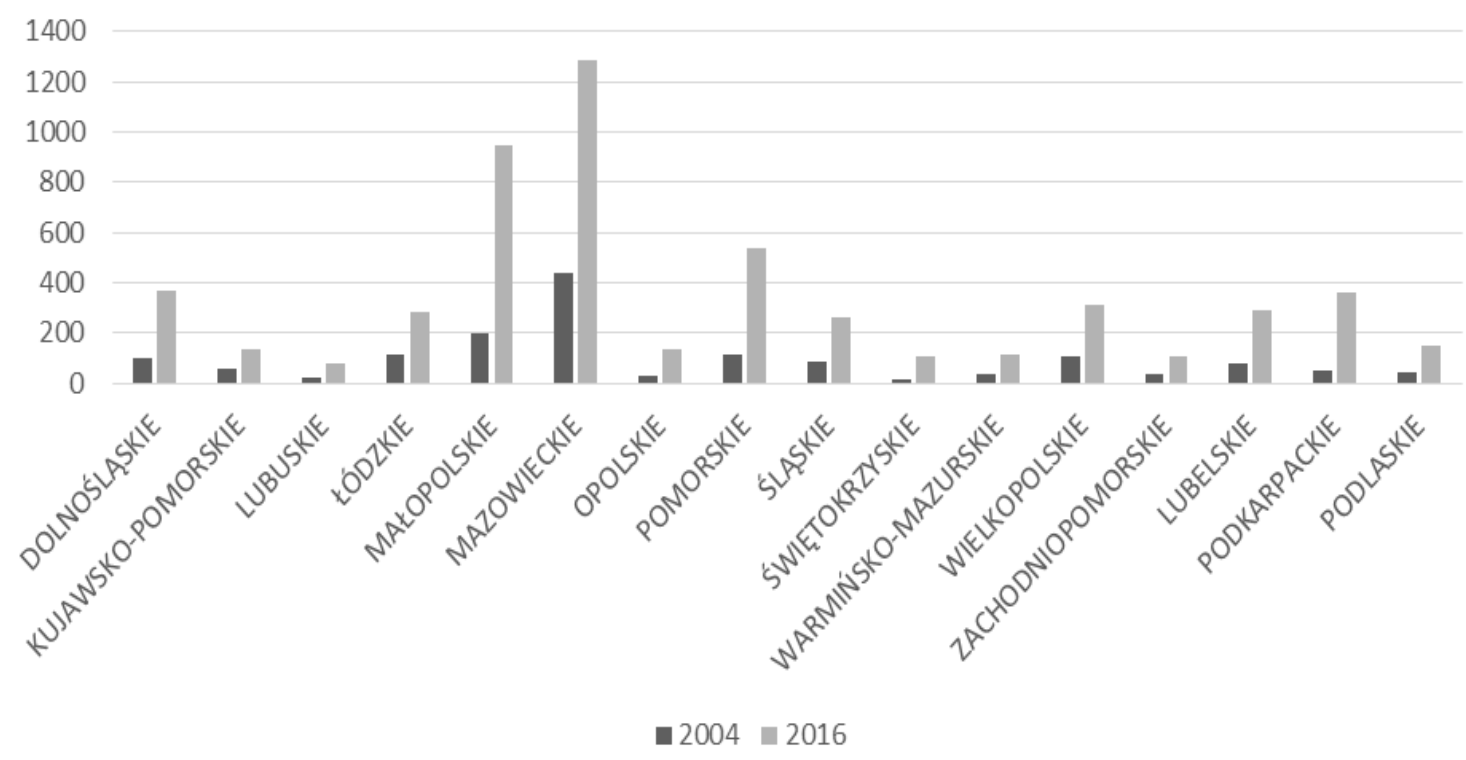

Source: Central Statistical Office

Fig. 2. R\&D expenditure in PLN per capita

The eastern borderland's demographic situation is gradually improving, which translates into new opportunities for socioeconomic development that the whole macro-region is facing at the moment. An analysis of the demographic dependency ratio used in the model (x2) showed that in the case of all the three eastern borderland voivodeships, their demographic situation improved. In 2004, Podlaskie Voivodeship came last among all Polish regions with a value of $\times 2=63.7$ (mean x2 value for Poland was 57.9 in 2004) In 2016, the demographic dependency ratio in this voivodeship amounted to 59.4, with Poland's mean value of 61.2. The demographic situation also improved in the other two voivodeships. Podkarpackie Voivodeship had a value of $\times 2=62.9$ in 2004 , and 62.3 in 2016. This means that despite all concerns, no massive demographic drain from the eastern for the benefit of the more developed parts of Poland borderland actually occurred. On the contrary, although the demographic situation is clearly worsening in Poland, the tendency observed in the eastern borderland voivodeships is quite the opposite.

\section{Conclusions, proposals, recommendations}

The development of border areas is determined by numerous processes and events. Our quantitative researched showed that Poland's eastern borderland encompassing three voivodeships continues to be one of Poland's regions with the lowest level of socioeconomic development. Lubelskie Voivodeship is the weakest in this category. Podkarpackie Voivodeship, in turn, made the largest progress between 2004 and 2016.

The following aspects should be highlighted as the main factors affecting the socioeconomic development of Poland's eastern borderland voivodeships: increasing innovativeness, growing R\&D expenditure, and good (though not yet fully utilized) investment attractiveness and attractiveness related to its location on the border.

The region's main weaknesses are their insufficient entrepreneurial activity levels and inadequate investment, including foreign investment. This may lead to problems with building or 
expanding the so-called business networks between the enterprises. It is highly important to regard such networks as means delivering essential opportunities for overcoming peripherality.

Any further socioeconomic development of Poland's eastern borderland voivodeships can be determined by, inter alia, developing their innovativeness through increasing R\&D expenditure and ensuring stronger cooperation between the higher education institutions and businesses, and by developing entrepreneurial attitudes among the region's inhabitants and creating conditions favourable to external investors.

\section{Bibliography}

1. Berry, B., Conkling, E., Ray, D.M., (1976). The Geography of Economic System, Englewoog Cliffs, PrenticeHall.

2. Copus, A.K., (2001). From Core-Periphery to Polycentric Development: Concepts of Spatial and a Spatial Peripherality, European Planning Studies, T.9, no 4, pp. 540-545.

3. Domanski, B., (2004). Krytyka pojecia rozwoju a studia regionalne (Critique of the Concept of Development and Regional Studies). Studia Regionalne i Lokalne, no 2(16), pp. 7-23.

4. Gluszczuk, D., (2011). Istota rozwoju regionalnego i jego determinanty (The Essence of Regional Development and its Determinants). Ekonomia (Economic), no 5(17), pp. 74.

5. Gorniak, J., Mazur, S., (2012). Zarzadzanie strategiczne rozwojem (Strategic Management of Development). Ministerstwo Rozwoju Regionalnego, Warszawa, pp. 15.

6. Greta, M., (2013). Euroregiony polskie w procesie integracji europejskiej oraz w przezwyciezaniu peryferyjnosci i dysproporcji regionalnych (Polish Euroregions in the Process of European Integration and in Overcoming Peripherality and Regional Disparities). Wydawnictwo Uniwersytetu Lodzkiego, Lodz, pp. 13.

7. Heffner, K., Gibas, P. , (2007). Analiza ekonomiczno-przestrzenna (Spatial Economic Analysis). Wydawnictwo Akademii Ekonomicznej w Katowicach, Katowice, pp. 12-13.

8. Idczak, P. , (2013). Wielowymiarowa koncepcja peryferyjnoci regionalnej. Identyfikacja regionów peryferyjnych w Polsce (Multidimensional Concept of Regional Peripherality. Identification of Peripheral Regions in Poland). Difin, Warszawa, pp. 80-121.

9. Indeks Millennium, (2017). Potencjal Innwacyjnosci Regionow (Millennium Index 2017. The Potential of Regional Innovation). Retrieved:

https://www.bankmillennium.pl/documents/10184/25989931/Indeks_Millennium_2017.pdf. Access: 31.01.2018.

10. Kucinski, K., (2009). Geografia ekonomiczna (Economic Geography). Wolters Kluwer, Krakow, pp. 423.

11. Malkowska, A., Malkowski, A., (2017). Eksport jako czynnik rozwoju wojewodztw wschodniego pogranicza Polski (Exports as a Factor in the Development of Poland's Eastern Borderland). Folia Pomeranae Universitatis Technologiae Stetinensis, Oeconomica, no 333(86)1, pp. 43-50.

12. Malkowski A., Malkowska A., (2013). Creating a Competetive Region on the Example of Pomerania Euroregion, Prace naukowe UE we Wroclawiu, no 315, Wyd. UE we Wroclawiu, Wroclaw, pp. 523-532.

13. Malkowski, A., (2015). Competitive Border Region Theory and Practice, Przedsiebiorczosc i Zarzadzanie, T. 16, cz. 2, z. 5, pp. 183-190.

14. Slaby, T., (2004). Nowe ujecie badan spolecznych (New Approach to Social Research). Nierownosci Spoleczne a Wzrost Gospodarczy 2004, no 4, pp. 57-66.

15. Strahl, D., (2006). Metody oceny rozwoju regionalnego (Methods for Assessing Regional Development). Wydawnictwo Akademii Ekonomicznej im. O. Langego we Wrocławiu, Wrocław.

16. Szewczuk, A., (2011). Rozwoj lokalny i regionalny jako przedmiot badan naukowych (Local and Regional Development as a Subject of Scientific Research) [in:] B. Filipiak, M. Kogut, A. Szewczuk, M. Ziolo, Rozwoj lokalny i regionalny. Uwarunkowania, finanse, procedury (Local and Regional Development. Conditions, Finances, Procedures). Fundacja na rzecz Uniwersytetu Szczecinskiego, Szczecin, pp. 9.

17. Szymla, Z., (2005). Podstawy badan rozwoju regionalnego (Basics of Regional Development Research). Zeszyty Naukowe WSE w Bochnii, no 3, pp. 101-111. 